\title{
PENANGGULANGAN STUNTING PADA BALITA MELALUI PELATIHAN PEMBUATAN NUGET SELUANG WALUH KEPADA KELOMPOK PKK KECAMATAN SUNGAI TABUK
}

\author{
Didik Dwi Sanyoto ${ }^{1}$, Triawanti ${ }^{1}$, Nurul Hidayah ${ }^{2}$, Nur Qomariah ${ }^{1}$, Athiya Nadifa ${ }^{1}$, \\ Muhammad Agung Perdana ${ }^{1}$ \\ ${ }^{1)}$ Fakultas Kedokteran, Program Studi Pendidikan Dokter, Universitas Lambung \\ Mangkurat \\ ${ }^{2)}$ Fakultas Kedokteran, Program Studi Profesi Dokter, Universitas Lambung Mangkurat \\ Email :triawanti@ulm.ac.id
}

\begin{abstract}
ABSTRAK
Prevalensi gizi kurang dan bawah garis merah pada balita di Kabupaten Banjar pada tahun 2016 sebesar 4,8\% dan masih ditemukan kasus gizi buruk sebanyak 8 kasus. Prevalensi stunting di kecamatan Sungai Tabuk tahun 2018 masuk dalam zona merah yaitu 39,76\%. Secara geografis kecamatan Sungai Tabuk merupakan daerah aliran Sungai Martapura yang menyimpan banyak potensi antara lain ikan seluang. Penanggulangan masalah gizi harus didukung oleh semua pihak, termasuk tim Penggerak PKK kecamatan. Mitra kegiatan adalah Tim PKK Kecamatan Sungai Tabuk dengan target sasaran masyarakat yaitu ibu-ibu PKK. Kegiatan bertujuan meningkatkan pengetahuan dan keterampilan ibuibu PKK dalam penanggulangan stunting. Kegiatan dilakukan secara luring yaitu penyuluhan dan pelatihan pembuatan nuget seluang waluh kepada ibu-ibu PKK dari tiap desa. Evaluasi kegiatan dilaksanakan berupa pretes dan postes sebelum pelatihan dan evaluasi pelaksanaan kegiatan. Kegiatan dihadiri oleh 25 peserta perwakilan PKK dari tiap desa. Rerata usia peserta 42 tahun dengan tingkat pendidikan SD sampai S1. Hasil pretes diperoleh nilai pengetahuan 9,38 dan postes 9,47. Respon peserta terhadap kegiatan yang dilakukan sangat baik, sebanyak $32 \%$ setuju dan $68 \%$ sangat setuju bahwa kegiatan ini bermanfaat buat mereka. Produk nuget seluang waluh yang didemonstrasikan mendapat antusias peserta, sebanyak $52 \%$ setuju dan $48 \%$ sangat setuju untuk mengolahnya di rumah.
\end{abstract}

Kata kunci: stunting, PKK, ikan seluang, waluh, nuget

\section{PENDAHULUAN}

Stunting merupakan suatu kegagalan untuk mencapai pertumbuhan yang optimal diukur berdasarkan tinggi badan per umur $(\mathrm{TB} / \mathrm{U})$ dikategorikan menjadi pendek dan sangat pendek. Laporan Riskesdas 2018 prevalensi pendek dan sangat pendek pada balita di Indonesia sebesar 30,8\%. Meskipun sudah mengalami penurunan dari tahun 2013 yang prevalensinya 37,2 tetapi tetap masih tinggi. Untuk baduta prevalensi pendek dan sangat pendek sebesar 29,9\%. Di Kalimantan Selatan prevalensi balita pendek dan sangat pendek tahun 2018 sebesar $31 \%$ dan baduta sebesar 24,2\% (Kementerian Kesehatan 2018). Berdasarkan Data dan 
Informasi Profil Kesehatan Indonesia tahun 2017 prosentase balita kurus dan sangat kurus di Kalimantan Selatan sebesar $10,2 \%$ diatas rata-rata nasional yang hanya 9,5\% (Kemenkes RI, 2017). Di Kabupaten Banjar pada tahun 2016 prevalensi gizi kurang dan BGM pada balita sebesar $4,8 \%$, masih ditemukan kasus gizi buruk sebanyak 8 kasus dan jumlah kecamatan yang bebas rawan gizi hanya berjumlah $6(31,5 \%)$ dari total 19 kecamatan. Kecamatan bebas rawan gizi adalah kecamatan dengan prevalensi gizi kurang dan gizi buruk $<15 \%$ selama kurun waktu tertentu (Dinas Kesehatan Kab. Banjar, 2017). Pada tahun 2018 hanya 8 wilayah kerja puskesmas yang bebas rawan gizi.

Jumlah penduduk kecamatan Sungai Tabuk pada tahun 2019 sebanyak 59.710 jiwa, terbanyak ke-2 setelah Martapura. Kecamatan Sungai Tabuk merupakan kecamatan yang belum bebas rawan gizi dengan kejadian gizi buruk yang tinggi dibandingkan kecamatan lain. Pada tahun 2018 terdapat 3 kasus gizi buruk (Kabupaten Banjar dalam Angka 2020). Prevalensi stunting di kecamatan Sungai Tabuk tahun 2018 masuk dalam zona merah yaitu 39,76\% (Seksi Kesga dan Gizi Dinas Kesehatan Kabupaten Banjar, 2018).
Secara geografis kecamatan Sungai Tabuk merupakan daerah aliran Sungai Martapura yang menyimpan banyak potensi sumber daya alam perairan yaitu berbagai jenis ikan air tawar termasuk ikan seluang. Sektor pertanian juga menjadi pendapatan utama penduduk Sungai Tabuk selain perikanan. Potensi sumber daya alam perairan dan pertanian ini tentunya dapat dijadikan sebagai solusi untuk penanggulangan masalah gizi khususnya gizi buruk dan stunting di kecamatan Sungai Tabuk.

Penanggulangan masalah gizi harus didukung oleh semua pihak, termasuk tim Penggerak PKK kecamatan. Dalam rangka berperan aktif dalam membantu terwujudnya pembangunan nasional, TP PKK harus tampil di depan untuk memberikan motivasi serta dukungan yang kongkrit kepada masyarakat. Tim Penggerak PKK berperan sebagai motivator, fasilitator, perencana, pelaksana, pengendali dan penggerak, serta pembinaan teknis kepada keluarga dan masyarakat, dilaksanakan dalam kerjasama dengan unsur dinas instansi pemerintah.

Penelitian Shalfiah menyimpulkan bahwa penyuluhan yang 
diberikan oleh PKK kota Bontang sudah banyak memberikan dukungan untuk pemerintah menjalankan berbagai program baik di bidang pendidikan, kesehatan maupun perekonomian. Pada penelitian Natsir dkk (2020) disimpulkan bahwa tim PKK dalam program perbaikan gizi keluarga di Desa Kanjilo Kabupaten Gowa dapat dikatakan sangat berperan dalam pemberian penyuluhan/dalam menjalankan fungsinya sebagai anggota PKK. Berdasarkan permasalahan yang ada dan potensi PKK kecamatan Sungai Tabuk maka perlu dilakukan kerjasama dengan Tim PKK Kecamatan Sungai Tabuk sebagai upaya penanggulangan masalah gizi di di Sungai Tabuk.

Selama ini Tim PKK Kecamatan Sungai Tabuk melaksanakan kegiatan secara rutin berupa arisan bulanan di setiap desa dan pembinaan administrasi desa ke desa (Tim PKK Kec. Sungai Tabuk 2020). Sampai saat ini belum ada kegiatan yang langsung menyentuh masalah gizi keluarga terutama masalah gizi buruk dan stunting. Upaya penanggulangan masalah tersebut lebih banyak diperankan oleh puskesmas. Oleh karena itu sangat diperlukan menggandeng tim PKK Kecamatan Sungai Tabuk sebagai mitra dalam kegiatan ini. Berdasarkan hasil analisis situasi dan uraian di atas maka dapat diambil penyebab dari permasalahan masih tingginya angka prevalensi stunting dan gizi buruk di Kecamatan Sungai Tabuk yaitu kurangnya peran tim PKK Kecamatan Sungai Tabuk dalam penanggulangan masalah stunting dan gizi buruk.

Solusi yang ditawarkan pada permasalahan ini yaitu melakukan penyuluhan dan pelatihan kepada ibuibu PKK tentang penanggulangan stunting dengan memanfaatkan potensi alam yang ada yaitu ikan seluang dan waluh (labu kuning). Ikan seluang (Rasbora argyrotaenia) merupakan ikan air tawar yang banyak ditemukan di sungai-sungai di Kalimantan Selatan. Kandungan gizi ikan seluang meliputi $\mathrm{Ca}, \mathrm{P}, \mathrm{Fe}, \mathrm{Zn}$, asam linoleat, asam linolenat, DHA dan 20 asam amino baik esensial maupun tidak esensial (Yunanto et al, 2015).

Selain ikan seluang juga digunakan waluh atau labu kuning sebagai bahan dasar makanan padat bergizi pada program pengabdian masyarakat ini. Waluh (Cucurbita moschata durch) banyak ditanam di Kabupaten Banjar dan sangat mudah ditemukan di pasarpasar di Sungai Tabuk. Penelitian 
tentang zat gizi labu kuning telah banyak dilakukan. Salah satunya yaitu retensi karoten dalam berbagai produk olahan labu kuning yang menyimpulkan bahwa retensi karoten pada produk kerupuk sebesar $79,44 \%$, biscuit $71,27 \%$ dan mie $64,46 \%$. Artinya walaupun sudah diolah menjadi berbagai produk kandungan beta karoten waluh tetap masih diatas $50 \%$ (Ranonto dkk, 2015).

Tujuan kegiatan ini yaitu meningkatkan pengetahuan dan keterampilan ibu-ibu PKK dalam penenggulangan stunting melalui pelatihan pembuatan nuget seluang waluh. Melalui kegiatan ini diharapkan ibu-ibu PKK dapat mengolah makanan bergizi tinggi yang disukai anak-anak dari bahan lokal. Dengan demikian maka stunting pada anak balita dapat dicegah.

\section{METODE PELAKSANAAN}

\section{Waktu Pelaksanaan}

Kegiatan ini dilaksanakan pada bulan Juli 2021 di pendopo desa Abumbun Jaya Kecamatan Sungai Tabuk dengan target sasaran masyarakat yaitu ibu-ibu anggota PKK Kecamatan Sungai Tabuk.

\section{Tahapan pelaksanaan}

Dalam upaya memberikan pengetahuan tentang gizi yang baik dan keterampilan untuk mengolah bahan makanan sederhana yang banyak tersedia menjadi makanan padat bergizi dan disukai oleh anak-anak pada ibu-ibu PKK maka akan dilaksanakan kegiatan yang meliputi :

A. Persiapan kegiatan

1. Melakukan diskusi dengan tim pengurus PKK Kecamatan Sungai Tabuk untuk menentukan metode pelatihan yang tepat

a. Melakukan pertemuan dan diskusi dengan tim pengurus PKK Kecamatan Sungai Tabuk di kantor kecamatan sesuai waktu yang disepakati,

2. Menetapkan jadwal pemberian pelatihan

3. Persiapan alat dan bahan membuat nuget seluang waluh

a. Membeli alat-alat dan bahan untuk mengolah nuget seluang waluh,

b. Mencoba resep nuget seluang waluh yang paling optimal dari segi rasa dan kandungan nilai gizinya.

4. Persiapan materi pelatihan Membuat materi pelatihan dalam bentuk PPT dan brosur yang akan dibagikan ke para peserta pelatihan 
B. Pelaksanaan kegiatan

Selama pelaksanaan kegiatan

seluruh peserta dan tim pengabdian mengikuti protokol kesehatan yaitu mencuci tangan, memeriksa suhu peserta, menjaga jarak dan memakai masker.

Memberikan pelatihan kepada ibu-ibu PKK:

a. Memberikan pengetahuan tentang gizi (gizi buruk, stunting, nilai gizi dan manfaat seluang dan waluh)

b. Mempraktekan cara pengolahan nuget seluang waluh yang sehat dan higienis.

Nuget seluang waluh dibuat dengan resep: 500 gram ikan seluang, 300 gram waluh, 100 gram tepung tapioca, 100 gram tepung terigu, telur ayam 2 butir, bumbu-bumbu (bawang merah, bawang putih, garam, kaldu jamur, daun seledri). Ikan seluang digiling kemudian dicampur dengan waluh yang sudah dikukus dan dihaluskan, ditambah tepung terigu dan tapioka serta bumbu-bumbu.
Adonan kemudian dikukus selama 30 menit, setelah matang didinginkan kemudian dipotong-potong sesuai selera dan dilumuri tepung panir. Selanjutnya digoreng ataupun dapat disimpam dalam lemari es.

c. Menyerahkan alat-alat pengolahan yang dibeli kepada tim PKK kecamatan agar dapat dipergunakan selanjutnya

C. Evaluasi kegiatan dilakukan bersama-sama dengan Ketua Tim PKK Kecamatan Sungai Tabuk dalam bentuk :

1. Pengisian kuisioner tentang materi pelatihan yang diisi oleh seluruh peserta sebelum dan sesudah pelatihan

2. Pengisian kuisioner tentang pelaksanaan kegiatan oleh seluruh peserta pelatihan setelah pelatihan selesai sebagai bahan evaluasi untuk tim pelaksana kegiatan pengabdian

3. Selanjutnya membuat komitmen bersama untuk tetap melanjutkan kegiatan tersebut walaupun program 
pengabdian pada masyarakat sudah berakhir.

\section{HASIL DAN PEMBAHASAN}

\section{Hasil Kegiatan}

Kegiatan pengabdian kemitraan masyarakat ini terlaksana pada tanggal 15 Juli 2021 yang dihadiri oleh 25 orang peserta dan 8 orang tim pengabdian. Karakteristik peserta disajikan pada Tabel 1.

Tabel 1. Karakteristik peserta pelatihan

\begin{tabular}{|c|c|c|}
\hline Karakteristik & Frekuensi & Persentase \\
\hline \multicolumn{3}{|l|}{ Umur } \\
\hline$<30$ tahun & 3 & 12 \\
\hline $30-50$ tahun & 16 & 64 \\
\hline$>50$ tahun & 6 & 24 \\
\hline \multicolumn{3}{|l|}{ Pendidikan } \\
\hline SD & 4 & 16 \\
\hline SMP & 3 & 12 \\
\hline SMA & 11 & 44 \\
\hline PT & 7 & 28 \\
\hline
\end{tabular}

bahwa Sebagian besar (64\%) peserta merupakan usia 30-50 tahun yang masih aktif dan produktif sehingga dapat menjadi penggerak masyarakat di lingkungannya masing-masing. Tingkat pendidikan peserta yang terbanyak yaitu SMA sebesar $44 \%$ dan $28 \%$ pendidikan tinggi. Dengan tingkat pendidikan tersebut anggota PKK kecamatan Sungai Tabuk dapat menjadi motivator dan inisiator di masyarakat.

Sebelum dan sesudah dilakukan penyuluhan dan pelatihan pembuatan nuget seluang waluh dilakukan prestes untuk mengetahui tingkat pengetahuan peserta tentang stunting dan makanan bergizi. Rerata nilai pretes yaitu 93,8 dan postes 94,7 . Jika dilihat dari nilai pretes dan postes maka tidak terlalu berbeda. Artinya peserta sudah memiliki pengetahuan yang baik tentang stnting dan makanan bergizi. Dari 10 pernyataan benar atau salah yang diajukan terdapat 1 butir pernyataan paling banyak salah yaitu tentang stunting (cebol) tidak berpengaruh pada kecerdasan anak. Sebagian besar menganggap pernyataan tersebut benar.

Setelah pretes dilakukan demontrasi cara pembuatan nuget seluang waluh disertai dengan penjelasan kandungn gizi dan manfaat dari masing-masing bahan tersebut. Demonstrasi pembuatan dan hasil nuget seluang waluh disajikan pada Gambar 1 dan 2 .

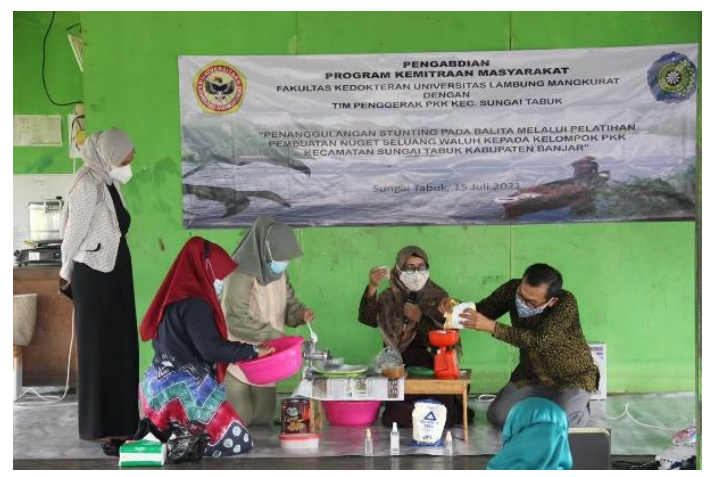

Gambar 1. Demonstrasi pembuatan nuget seluang waluh 


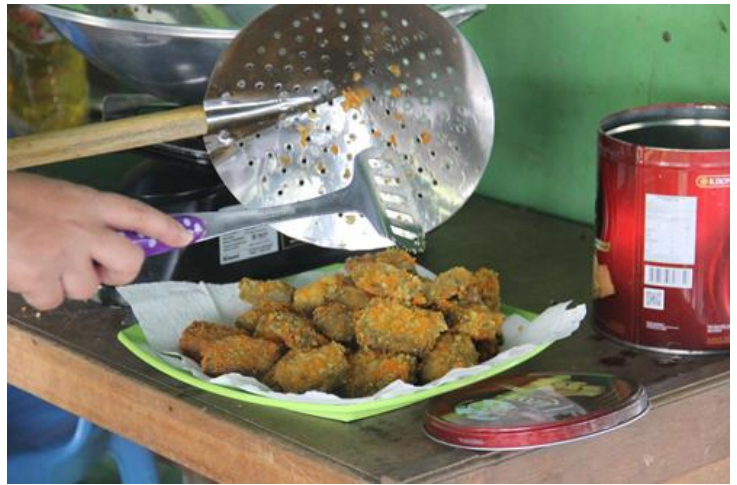

Gambar 2. Hasil olahan nuget seluang waluh

Selain demonstrasi pembuatan nuget seluang waluh juga diberikan penyuluhan tentang tumbuh kembang anak dan stunting. Materi yang diberikan meliputi tumbuh kembang anak, penyebab stunting, dampak negative stunting dan cara pencegahannya (Gambar 3).

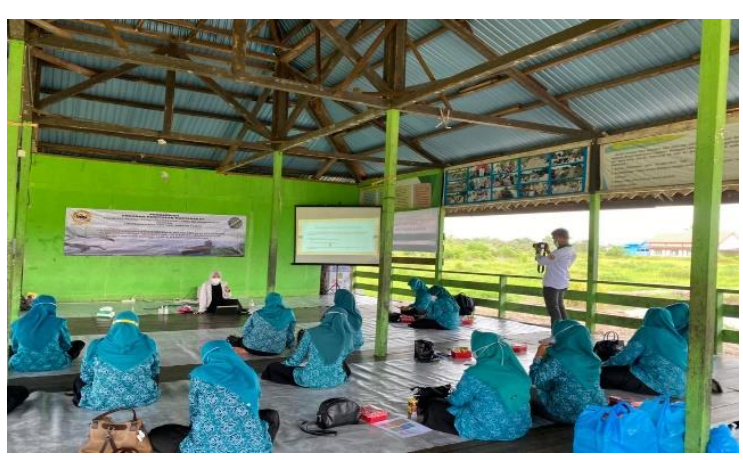

Gambar 3. Penyuluhan tentang tumbuh kembang anak dan stunting

\section{Setelah selesai kegiatan} demonstrasi dan penyuluhan, seluruh peserta dipersilakan untuk mencicipi nuget seluang waluh yang telah masak.
Pada kegiatan ini peserta juga diminta mengisi kuisioner evaluasi kegiatan yang terdiri atas tanggapan terhadap pelaksanaan kegiatan dan hasil olahan nuget seluang waluh. Hasil tanggapan peserta disajikan pada Tabel 2.

Berdasarkan Tabel 2 dapat terlihat bahwa secara keseluruhan peserta setuju dan sangat setuju bahwa kegiatan ini menarik, memiliki manfaat dan tujuannya jelas. Sementara itu tanggapan terhadap olahan nuget seluang waluh Sebagian besar setuju dan sangat setuju bahwa nuget seluang waluh memnuhi selera dan akan disukai anak-anak serta peserta akan mencoba mengolahnya di rumah.

\section{Pembahasan}

Kelompok PKK merupakan kelompok potensial yang dapat memberdayakan masyarakat bukan hanya ibu rumah tangga tetapi seluruh anggota keluarga yang ada di komunitas/masyarakat. Pada program pengabdian ini yang menjadi kelompok mitra yaitu Tim Penggerak PKK Kecamatan Sungai Tabuk. Pada saat sosialisasi, peserta yang hadir kebanyakan berumur 30-50 tahun yaitu 64\% dan memiliki tingkat pendidikan rata-rata SMA sebesar 44\% dan PT 28\% (Tabel 1). Dengan demikian dapat 
dikatakan bahwa kelompok mitra sangat potensial untuk menyebarluaskan informasi yang diberikan kepada anggota PKK secara khusus dan masyarakat pada umumnya dan berperan sebagai agent of change di masyarakat. Usia 30-50 tahun merupakan usia yang matang, penuh pengalaman, produktif dan sering menjadi panutan di masyarakat, sehingga apa yang disampaikan oleh kelompok ini lebih mudah diterima oleh masyarakat dibanding kelompok yang masih berusia muda. Selain itu pendidikan yang dimiliki kelompok mitra terbanyak adalah SMA dan Perguruan Tinggi sehingga lebih mudah menerima dan mengadopsi informasi yang diberikan kemudian meneruskan kepada anggota PKK ataupun masyarakat secara luas. Tingkat pendidikan yang dimiliki oleh kelompok mitra menjadi modal besar dalam peran kelompok ini sebagai inisiator dan motivator di masyarakat. Setiap informasi yang disampaikan akan diterima dan dipercaya oleh masyarakat karena dianggap sebagai kelompok yang pintar.

Tingkat pendidikan seseorang akan berhubungan dengan pengetahuan yang dimilikinya. Hal ini terlihat pada hasil pretes dan postes yang rata-rata diatas
90. Seluruh peserta sosialisasi memperoleh skor 80 ke atas, bahkan banyak yang memperoleh nilai 100 baik pada saat pretes maupun postes. Artinya, peserta sosialisasi sudah mengetahui tentang stunting dan makanan bergizi. Hal ini menjadi kekuatan bagi ibu-ibu Tim Penggerak PKK Kecamatan Sungai Tabuk untuk menyebarluaskan informasi yang telah didapat kepada anggota masyarakat lain di lingkungannya.

Antusiasme peserta terhadap pelatihan pembuatan nuget seluang waluh ini sangat baik. Hal ini terlihat dari tanggapan mereka yang Sebagian besar setuju dengan manfaat kegiatan dan akan mempraktekkannya di rumah masing-masing (Tabel 2).

Ikan seluang biasa dikonsumsi oleh masyarakat luas karena rasanya yang gurih dan harganya relatif terjangkau oleh seluruh lapisan. Ikan berukuran maksimal $170 \mathrm{~mm}$ ini sering dikonsumsi dalam bentuk digoreng atau dipepes dengan seluruh bagian ikan kecuali isi perut. Oleh karena dimakan bersama dengan seluruh tulangnya maka sangat baik untuk memenuhi kebutuhan kalsium, $\mathrm{Fe}$ dan mineral lain. Kandungan gizi ikan seluang meliputi $\mathrm{Ca}, \mathrm{P}, \mathrm{Fe}, \mathrm{Zn}$, asam linoleat, asam 
linolenat, DHA dan 20 asam amino baik esensial maupun tidak esensial (Yunanto et al, 2015). Beberapa penelitian tentang potensi seluang sebagai sumber nutrisi antara lain ikan seluang dapat memperbaiki stress oksidatif otak pada tikus malnutrisi (Triawanti et al, 2017), ikan seluang memperbaiki status nutrisi pada tikus pasca malnutrisi yaitu dengan meningkatkan kadar hormon pertumbuhan, kadar protein, kadar $\mathrm{Hb}$ dan kalsium tulang (Triawanti et al, 2018) dan ikan seluang dapat memperbaiki memori spasial dan meningkatkan ekspresi PPAR gamma pada tikus pasca malnutrisi (Yunanto et al, 2015). Ikan seluang juga terbukti dapat memperbaiki neurotoksisitas pada tikus yang induksi endosulfan sebagai model autism (Triawanti et al, 2019).

Selain seluang yang banyak kandungan gizi dan manfaatnya juga digunakan waluh pada olahan nuget ini. Waluh (Cucurbita moschata durch) banyak ditanam di Kabupaten Banjar dan sangat mudah ditemukan di pasarpasar di daerah Sungai Tabuk. Kandungan gizi 100 gram labu kuning yaitu energi $51 \mathrm{kkal}$, lemak total 0,50 gram, beta karoten $1569 \mathrm{mcg}$, vitamin C $2 \mathrm{mg}$, protein 1,70 gram, serat $2,70 \mathrm{~g}$, kalsium $40 \mathrm{mg}$, fosfor $180 \mathrm{mg}$, natrium $280 \mathrm{mg}$, kalium $220 \mathrm{mg}$, tembaga 350 $\mathrm{mg}$, zat besi 0,70 mg, seng 1,50 mg (nilai gizi.com 2020). Waluh juga mengandung antioksidan yang sangat penting untuk melawan stres oksidatif akibat berbagai faktor. Aktivitas antioksidan bubuk waluh sebesar 6765.88 ppm (Junita et al, 2017).

Nuget seluang waluh yang dipraktekkan ini memiliki rasa yang enak dan diyakini peserta akan disukai anak-anak. Kandungan gizi pada nuget seluang waluh telah dihitung yaitu dalam 100 gram produk mengandung 280 kkalori; 7,729 gram protein; 2,912 gram lemak; 470 mcg beta karoten; 4,8 IU vitamin A; $52 \mathrm{mg}$ kalsium dan 2,56 mg zat besi.

Nuget seluang waluh selain dapat meningkatkan gizi keluarga dan mencegah stunting diharapkan juga dapat menjadi usaha rumah tangga. Diharapkan masyarakat mampu mengolah bahan-bahan lokal selain ikan seluang dan waluh untuk menjadi produk olahan yang bernilai gizi tinggi sehingga dapat meningkatkan kesehatan dan ekonomi keluarga. 
Tabel 2. Prosentase tanggapan peserta terhadap pelaksanaan kegiatan

\begin{tabular}{|c|c|c|c|c|c|}
\hline Pernyataan & $\begin{array}{l}\text { ST } \\
\text { S }\end{array}$ & TS & $\mathrm{R}$ & S & SS \\
\hline Kegiatan ini menarik & 0 & 0 & 0 & 32 & 17 \\
\hline Kegiatan ini memilki manfaat untuk ibu-ibu & 0 & 0 & 0 & 32 & 17 \\
\hline Tujuan dari kegiatan ini jelas & 0 & 0 & 0 & 40 & 15 \\
\hline Kegiatan ini tidak memenuhi harpan peserta & 32 & 28 & 4 & 28 & 2 \\
\hline $\begin{array}{l}\text { Proses penjelasan pembuatan nugget seluang waluh ini } \\
\text { menggunakan bahasa yang mudah dimengerti }\end{array}$ & 0 & 0 & 0 & 44 & 14 \\
\hline Brosur pengabdian ini menarik & 0 & 0 & 4 & 80 & 4 \\
\hline Beberapa kalimat dalam brosur membingungkan & 20 & 36 & 4 & 40 & \\
\hline Makanan nuget seluang waluh yang dibuat memnuhi selera & 0 & 0 & 0 & 44 & 14 \\
\hline Makanan nuget seluang waluh akan disukai anak-anak & 0 & 0 & 4 & 52 & 11 \\
\hline $\begin{array}{l}\text { Setelah melihat demo pembuatan nuget ini menimbulkan } \\
\text { keinginan untuk mencoba di rumah }\end{array}$ & 0 & 0 & 0 & 52 & 12 \\
\hline
\end{tabular}

Keterangan: STS = sangat tidak setuju, TS = tidak setuju, $\mathrm{R}=$ ragu-ragu, $\mathrm{S}=$ setuju, $\mathrm{SS}$ = sangat setuju

\section{KESIMPULAN DAN SARAN}

\section{Kesimpulan}

Kegiatan pelatihan pembuatan nuget seluang waluh bagi ibu-ibu PKK dapat menjadi alternatif dalam penanggulangan masalah stunting pada balita. Selain itu dapat dijadikan sebagai usaha rumah tangga. Partisipasi dan tanggapan peserta pelatihan sangat baik. Nuget seluang waluh diyakini akan disukai anak-anak.

\section{Saran}

Untuk tim penggerak PKK Kecamatan Sungai Tabuk agar lebih banyak lagi melakukan inovasi terkait dengan produk makanan olahan dengan bahan dasar lokal yang banyak ditemukan di daerah tersebut menjadi makanan bergizi tinggi dan bernilai ekonomis. Untuk masyarakat agar lebih memperhatikan tumbuh kembang anak dan Kesehatan ibu hamil agar kejadian stunting dapat dicegah.

\section{UCAPAN TERIMAKASIH}

Terimakasih disampaikan kepada Fakultas Kedokteran Universitas Lambung Mangkurat yang telah memberikan dana untuk kegiatan pengabdian ini melalui hibah PKM FK ULM. Terimakasih juga disampaikan kepada Bapak Camat dan Tim PKK Sungai Tabuk. 


\section{DAFTAR PUSTAKA}

Badan Pusat Statistik Kabupaten Banjar, 2020. Kabupaten Banjar dalam Angka 2020.

Dinkes Kabupaten Banjar, 2017. Profil Kesehatan Kabupaten Banjar.

Junita D, Setiawan B, Anwar F, Muhandri T, 2017. Komponen Gizi, Aktivitas Antioksidan dan Karakteristik Sensori Bubuk Fungsional Labu Kuning (Cucurbita moschart) dan Tempe. J. Gizi Pangan 12(2):109-116.

Kemenkes RI 2017. Data dan Informasi Profil Kesehatan Indonesia 2017

Kemenkes RI. 2018. Hasil Utama Riset Kesehatan Dasar 2018. Jakarta: Indonesia

Natsir N, Gaffar F, Syawaluddin A. 2020. Peranan Tim Penggerak Pemberdayaan dan Kesejahteraan Keluarga Dalam Upaya Perbaikan Gizi Keluarga. JIKAP PGSD 4(2):170-178.

Nilai Kandungan Gizi Labu Kuning. 2021 diunduh dari https://nilaigizi.com/gizi/detailpr oduk/504/nilai-kandungan-gizilabu-kuning-segar

Ranonto NR, Nurhaeni, Razak AR. 2015. Retensi Karoten Dalam Berbagai Produk Olahan Labu Kuning (Cucurbita moschata Durch). Online Jurnal of Natural Science 4(1) :104-110.

Seksi KESGA dan Gizi Dinas Kesehatan Kabupaten Banjar, 2018. Prevalensi Stunting per Desa di Kabupaten Banjar Berdasarkan
Tingkat Keparahan (Merah: tinggi; Kuning: sedang; Hijau: rendah).

Shalfiah R, 2013. Peran Pemberdayaan dan Kesejahteraan Keluarga (PKK) dalam Mendukung Program-Porgram Pemerintah Kota Bontang. eJournal Ilmu Pemerintahan 1(3):975-984.

Triawanti T, Sanyoto DD, Nur'amin HW, 2017. Reduction of Oxidative Stress by Seluang Fish (Rasbora spp.) in Brain of Malnourished Rats (Rattus norvegicus). ETP Int J Food Eng 3: 107-111.

Triawanti, Sanyoto DD, Noor MS. 2019. The seluang fish (Rasbora spp.) diet to improve neurotoxicity of endosulfan-induced intrauterine pup's brain through of oxidative mechanism. Clinical Nutrition Experimental 28:74-82.

Triawanti T, Yunanto A, Dwi Sanyoto D, Wana Nuramin H, 2018. Nutritional Status Improvement in Malnourished Rat (Rattus norvegicus) after Seluang Fish (Rasbora spp.) Treatment. Curr Res Nutr Food Sci J 6: 127-134.

TP PKK. 2020. Profil PKK Kecamatan Sungai Tabuk

Yunanto A, Sanyoto DD, Noor MS, Oktavianti I, Triawanti, 2015. The Quality of Rat Brain Spatial Memory and Expression of Peroxisome Proliferator Activated Receptor (PPAR) which Fed with seluang (rasbora spp). Journal Of Life Sciences and Technologies $3(2): 43-47$. 